\title{
Pengembangan Bahan Ajar Fisika Berbasis Way of Investigating untuk Meningkatkan Keterampilan Proses Siswa SMK
}

\author{
O. I. Permatasari ${ }^{*}$ dan D. Trisnawati ${ }^{2}$ \\ 1SMK Walisongo Kaliori Rembang, Indonesia \\ ${ }^{2} S M A$ Negeri 1 Kragan, Indonesia \\ *Email:obiem.mieta@gmail.com
}

Received: May 19th 2021. Accepted: July 22 ${ }^{\text {th }}, 2021$. Published: August 29th 2021

\begin{abstract}
Abstrak
Keterampilan proses merupakan hal yang sangat penting di dalam pembelajaran. Keterampilan proses dapat didekati dengan cara menyelidiki suatu fenomena. Penelitian ini bertujuan mengembangkan bahan ajar Fisika berbasis way of investigating untuk meningkatkan keterampilan proses siswa. Penelitian ini menggunakan desain Research and Development (R\&D). Metode pengumpulan data yang digunakan adalah tes, observasi, angket, dan dokumentasi. Sampel penelitian diambil secara purposive sampling. Berdasarkan analisis data, diketahui bahwa bahan ajar yang dikembangkan berkategori sangat valid dan layak digunakan dengan rerata nilai sebesar 89,97. Keterbacaan bahan ajar berada pada kategori baik dengan nilai 77,88. Uji gain keterampilan proses pada kelas eksperimen sebesar 0,303 berada dalam kategori sedang, sedangkan pada kelas kontrol sebesar 0,297 berada dalam kategori rendah. Respons siswa terhadap bahan ajar yang dikembangkan sangat baik, dengan persentase rata-rata $86,65 \%$. Hasil penelitian ini menunjukkan bahwa bahan ajar berbasis way of investigating layak digunakan dalam pembelajaran fisika, terutama untuk meningkatkan keterampilan proses siswa.
\end{abstract}

\begin{abstract}
Process skills are very important in learning. Process skills can be approached by investigating a phenomenon. This research aims to develop way of investigating physics teaching materials to improve students' process skills. This study uses a Research and Development
\end{abstract}


(R\&D) design. Data collection methods used are tests, observations, questionnaires, and documentation. The research sample was taken by purposive sampling. Based on data analysis, it is known that the teaching materials developed are categorized as very valid and suitable for use with an average value of 89.97. The readability of teaching materials is in the good category with a value of 77.88 . The process skill gain test in the experimental class of 0.303 is in the medium category, while in the control class of 0.297 is in the low category. Student responses to the developed teaching materials are very good, with an average percentage of $86.65 \%$. The results of this study indicate that way of investigating teaching materials are appropriate to be used in physics learning, especially to improve students' process skills.@2021PERJ

Keywords: Teaching materials; Way of Investigating; process skills.

\section{PENDAHULUAN}

Abad ke-21 merupakan abad globalisasi yang penuh persaingan dan juga tantangan yang ditandai dengan semakin canggihnya teknologi dan perkembangan sains yang sangat cepat. Sains akan berperan sangat penting dalam aspek kehidupan manusia dan harus dapat diimbangi dengan kualitas pembelajaran yang ada (Susanti et al., 2015).

Rendahnya keterampilan proses siswa dipengaruhi banyak hal, yaitu kurikulum dan sistem pendidikan, pemilihan metode dan model pengajaran oleh guru, fasilitas, gaya belajar, sumber belajar, dan lain sebagainya (Mar'ah, 2016). Oleh karena itu, untuk meningkatkan keterampilan proses dibutuhkan suatu strategi belajar mandiri meliputi konsep konkret yang sesuai dengan kehidupan siswa sehari-hari, salah satunya adalah dengan bahan ajar mandiri untuk siswa. Kunci sukses keberhasilan pendidikan adalah aktivitas siswa. Guru harus mampu mendisiplinkan siswa, terutama disiplin diri untuk mengembangkan aktivitas siswa (Muslimin, 2011).

Kumpulan pengetahuan yang menjadi kesatuan utuh yang bermakna disebut hakekat sains. Hakekat sains terdiri atas beberapa komponen, yaitu: produk untuk pengganti pernyataan sains sebagai sebuah kumpulan pengetahuan ( $a$ body of knowledge), sains sebagai proses untuk pengganti pernyataan sains sebagai cara untuk penyelidikan dan interaksi sains (way of investigating), sains sebagai sikap untuk pengganti pernyataan sains sebagai cara berpikir (way of thinking), dan mengkaitkan antara sains dan teknologi dengan masyarakat (interaction of science, technology, and society) (Chiappetta et al., 1991).

Pembelajaran Fisika pada kulikulum 2013 untuk jenjang SMA/SMK dilakukan menggunakan 
pendekatan saintifik yang terintegrasi pada keterampilan proses dalam menemukan konsep Fisika. Kemampuan siswa dalam memahami konsep sains yaitu dengan mengaplikasikan di kehidupan seharihari dan dapat menjelaskan fenomena tersebut berdasarkan bukti-bukti secara ilmiah (Cansiz \& Turker, 2011).

Pembelajaran dengan pendekatan way of investigating dapat membantu siswa dalam melakukan tahapantahapan dalam melakukan praktikum untuk mendapatkan konsep yang benar dengan cara yang mudah. Way of investigating adalah salah satu cara untuk membantu siswa dalam mempelajari keterampilan proses.

Keterampilan proses sangat penting bagi perkembangan siswa dalam menanamkan pengetahuan dan mengaktifkan siswa (Lestari \& Diana, 2018; Rahmatillah et al., 2017). Penggunaan keterampilan proses diharapkan dapat membuat siswa memahami materi yang disampaikan dengan baik, sehingga dapat berguna dikemudian hari.

Pembelajaran way of investigating sangat cocok bagi siswa SMK karena dapat membantu meningkatkan keterampilan proses yang dibutuhkan dalam praktik di lapangan. Materi Tekanan juga merupakan materi yang sangat penting untuk dikuasai siswa SMK pada bidang keahlian Teknik Kendaraan Ringan Otomotif karena akan berkaitan dengan peralatan yang digunakan di bengkel.
Berdasarkan uraian tersebut, perlu dikembangan bahan ajar Fisika berbasis way of investigating yang dapat membantu siswa dalam berpikir secara terintegrasi, tidak hanya menguasai dimensi konten saja, tetapi dapat memahami dimensi proses dan konteks yang berguna bagi siswa dikemudian hari tentang materi Tekanan. Bahan ajar yang dikembangkan memiliki fitur lengkap dengan tahapan yang jelas, sehingga memudahkan siswa dalam mempelajari materi; dan bahan ajar dicetak dengan ukuran $25 \mathrm{~cm} \times 20 \mathrm{~cm}$ sehingga mudah untuk digunakan.

\section{METODE}

Penelitian pengembangan bahan ajar Fisika berbasis way of investigating menggunakan prosedur Research \& Development (R \& D) yang diadaptasi dari Sugiyono (2010). Tahapan yang dilakukan dalam penelitian pengembangan ini yaitu: (1) tahap pendahuluan, dimulai dengan studi literatur, observasi kondisi yang ada di lapangan untuk mengetahui potensi masalah dan analisis kebutuhan, serta wawancara dengan guru untuk mendapatkan informasi tentang pembuatan bahan ajar; (2) tahap perencanaan, meliputi pembuatan desain bahan ajar fisika berbasis way of investigating kelas $\mathrm{X}$ pada materi Tekanan, penentuan kompetensi inti 
dan kompetensi dasar, tujuan pembelajaran, kompenen yang ditampilkan, dan langkah pengukuran hasil belajar; (3) tahap pengembangan, yaitu validasi bahan ajar dan uji coba produk.

Uji ahli/validasi dilakukan oleh satu guru senior Fisika dari luar SMK Walisongo Kaliori, satu ketua MGMP Fisika SMK Kabupaten Rembang, dan satu guru Fisika teman sejawat sebagai praktisi. Produk yang telah dinyakatakan valid selanjutkan diujicoba kepada siswa. Uji coba dilakukan menggunakan desain eksperimen. Desain penelitian pada tahap uij coba dapat dilihat pada Tabel 1.

Tabel 1 Desain Penelitian

\begin{tabular}{cccc}
\hline Sampel & $\begin{array}{c}\text { Kondisi } \\
\text { Awal }\end{array}$ & Perlakuan & $\begin{array}{c}\text { Kondisi } \\
\text { Akhir }\end{array}$ \\
\hline $\mathrm{E}$ & $\mathrm{O}_{1}$ & $\mathrm{X}$ & $\mathrm{O}_{2}$ \\
$\mathrm{~K}$ & $\mathrm{O}_{3}$ & & $\mathrm{O}_{4}$ \\
\hline
\end{tabular}

Keterangan :

E : kelas eksperimen

$\mathrm{K}$ : kelas kontrol

$X$ : pembelajaran dengan bahan ajar yang dikembangkan

$\mathrm{O}_{1}$ dan $\mathrm{O}_{3}$ : pre-test pada kelas eksperimen dan kelas kontrol

$\mathrm{O}_{2}$ dan $\mathrm{O}_{4}$ : post-test pada kelas eksperimen dan kelas kontrol

Populasi dalam penelitian ini adalah seluruh siswa kelas X SMK Walisongo Kaliori Rembang yang terdiri atas 3 kelas. Sampel penelitian diambil secara purposive sampling, dengan kelas $X$ TKRO A sebagai kelompok eksperimen dan kelas $\mathrm{X}$ TKRO B sebagai kelompok kontrol.

Data dalam penelitian ini meliputi data kuantitaif dan data kualitatif. Data kuantitatif berupa data tentang skor pre-test dan post-test yang diperoleh siswa dalam pembelajaran materi Tekanan. Data kualitatif terdiri atas data tentang sikap siswa, kegiatan selama melakukan praktikum, respons siswa mengenai bahan ajar yang dikembangkan dan hasil wawancara mengenai keunggulan dan keterbatasan bahan ajar yang dikembangkan, serta kendala yang dijumpai sehubungan dengan penerapan bahan ajar.

Metode pengumpulan data dalam penelitian ini adalahsebagai berikut:

1) Metode dokumentasi, untuk mendapatkan data mengenai kemampuan awal siswa yang menjadi sampel penelitian.

2) Metode tes, digunakan untuk mengetahui kemampuan keterampilan proses siswa. Tes yang digunakan adalah tes objektif disertai alasan. Analisis metode tes soal objektif disertai alasan ini adalah dengan menggunakan skor 3-0. Skor 3 untuk jawaban benar dan alasan tepat, skor 2 untuk jawaban benar dan alasan kurang tepat, skor 1 untuk jawaban benar dan alasan salah dan skor 0 untuk jawaban salah. Penelitian ini mengujicobakan 30 butir soal tes 
kepada 20 siswa. Hasil uji coba soal tes ini dianalisis untuk menentukan validitas, reliabilitas, daya beda dan tingkat kesukaran soal.

3) Metode observasi, digunakan untuk mengukur kompetensi keterampilan proses, mengetahui aktivitas semua siswa pada proses pelaksanaan pembelajaran di kelas eksperimen dan kelas kontrol.

4) Metode angket, digunakan untuk mengetahui respons terhadap bahan ajar yang dikembangkan. Analisis metode observasi dan angket ini menggunakan teknik rating scale, yaitu skor 1 untuk tidak baik, skor 2 untuk cukup baik, skor 3 untuk baik dan skor 4 untuk sangat baik.

\section{HASIL DAN PEMBAHASAN}

Bahan ajar yang dikembangkan terdiri atas sampul depan, kata pengantar, KI dan KD yang akan dicapai dalam kegiatan pembelajaran, petunjuk belajar, sajian isi buku, daftar isi, penyelidikan sains dengan berbasis way of investigating yang memuat keterampilan proses, penjelasan materi, diskusi, zona berpikir, tokoh sains, info sains, rangkuman, uji kompetensi yang berisi pertanyaan mengenai bab yang dibahas, kunci jawaban, glosarium, dan daftar pustaka.

Sebelum diujicobakan, bahan ajar terlebih dahulu divalidasi oleh tiga validator untuk menilai validitas dan kelayakannya. Skor dari masingmasing validator dirata-rata hingga diperoleh skor akhir. Rata-rata skor validitas dan kelayakan bahan ajar dari ketiga validator adalah 89,97 dapat dilihat pada Tabel 1.

Tabel 1. Rekapitulasi Penilaian Kevalidan dan Kelayakan Bahan Ajar

\begin{tabular}{|c|c|c|c|c|c|c|c|}
\hline \multirow[b]{2}{*}{ No } & \multirow[b]{2}{*}{ Validator } & \multicolumn{5}{|c|}{ Aspek yang Dinilai } & \multirow{2}{*}{$\begin{array}{l}\text { Rata- } \\
\text { rata }\end{array}$} \\
\hline & & Isi & Penyajian & Bahasa & Kegrafikan & $\begin{array}{l}\text { Keterampilan } \\
\text { Proses }\end{array}$ & \\
\hline 1 & $\mathrm{~V}-1$ & 88 & 88 & 90 & 92 & 83 & 88 \\
\hline 2 & $\mathrm{~V}-2$ & 88 & 93 & 90 & 90 & 92 & 90 \\
\hline 3 & V-3 & 92 & 88 & 95 & 90 & 92 & 91 \\
\hline \multicolumn{2}{|c|}{ Rata-rata } & 88,89 & 89,62 & 91,67 & 90,67 & 88,89 & 89,97 \\
\hline \multicolumn{2}{|c|}{ Kategori } & \multicolumn{6}{|c|}{ Sangat valid } \\
\hline
\end{tabular}

Validasi bahan ajar yang dikembangkan memeroleh nilai 89,97 yang termasuk kategori sangat valid sehingga layak untuk digunakan dalam pembelajaran. Kevalidan dan kelayakan bahan ajar ini diuji dengan 
menggunakan standar dari BSNP yang meliputi: kelayakan isi, kelayakan penyajian, kelayakan bahasa dan kelayakan kegrafikan (Hartono, 2013).

Berdasarkan analisis tes rumpang, diketahui bahwa tingkat keterbacaan bahan ajar yang dikembangkan memiliki skor 77,88 atau termasuk mudah dipahami sesuai kriteria Bormuth. Faktor yang memengaruhi tingkat keterbacaan adalah kemampuan membaca, keakuratan ilustrasi, dan ketertarikan dari siswa. Buku teks yang layak digunakan dalam pembelajaran memiliki keriteria keterbacaan baik, serta panjang kalimat dan pemilihan bahasa yang sesuai (Muslimin, 2011). Penggunaan bahasa yang sesuai dengan perkembangan usia siswa pada bahan ajar akan mempermudah pemahaman materi yang disajikan. Bahan ajar yang baik mempunyai kriteria keterbacaan mudah dipahami dan dapat memberdayakan kemampuan berpikir siswa (Ilmi et al., 2016; Kurnia et al., 2014).

Keterampilan proses dinilai melalui kegiatan praktikum sesuai dengan yang disajikan dalam bahan ajar yang digunakan. Penilaian keterampilan proses dilakukan pada dua kali praktikum. Terdapat tujuh indikator yang dilihat pada kegiatan praktikum. Nilai ketujuh indikator tersebut dapat dilihat pada Gambar 1 untuk praktikum I dan Gambar 2 untuk praktikum II, baik di kelas eksperimen maupun kelas kontrol.

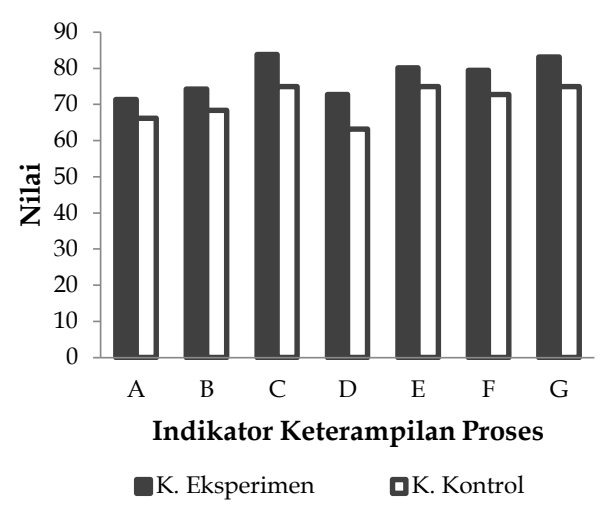

Gambar 1. Hasil Praktikum I



Gambar 2. Hasil Praktikum II

Indikator keterampilan proses

dijelaskan sebagai berikut:

A : Menyiapkan alat

B : Merangkai alat

C : Melaksanakan dan mencatat

D : Menganalisis dan

mengkomunikasikan kesimpulan

E : Kejujuran

F : Ketelitian

G : Tanggungjawab

Keterampilan proses yang dinilai dari kegiatan praktikum dengan tujuh indikator. Capaian tertinggi untuk kelas eksperimen dan kelas kontrol terdapat pada indikator melaksanakan 
dan mencatat hasil praktikum. Hal ini sesuai dengan pendekatan yang digunakan yaitu berbasis way of investigating. Siswa dilatih untuk menginvestigasi permasalahan dalam fisika dan dilatih untuk mengemukakan pendapat. Ketertarikan dan antusias di dalam pembelajaran dengan menggunakan alat laboratorium dapat mempermudah siswa dalam melakukan way of investigating untuk meningkatkan keterampilan proses pada materi tekanan (Hanisa, 2013).

Pada indikator menganalisis dan mengkomunikasikan kesimpulan, di kedua kelas mendapat nilai paling rendah. Hal ini disebabkan siswa belum terbiasa untuk menganalisis dan menyimpulkan hasil dari kegiatan yang telah dilakukan dan terdapat rasa takut untuk menyampaikan pendapat. Meskipun demikian, terdapat peningkatan dari praktikum I ke praktikum II. Oleh karena itu, kegiatan pembelajaran semacam ini harus selalu ditanamkan dan dilatih agar pola pikir siswa dapat terstruktur dengan baik. Pada indikator sikapjuga terdapat peningkatan, karena pada setiap pembelajaran selalu ditanamkan sikap jujur, teliti dan tanggung jawab.

Data untuk uji gain keterampilan proses kelas eksperimen dan kelas kontrol diperoleh melalui nilai lembar observasi praktikum I dan II. Nilai ngain pada kelas eksperimen sebesar 0,303 berada dalam kategori sedang, sedangkan kelas kontrol sebesar 0,297 berada dalam kategori rendah. Bahan ajar yang mendapatkan respons positif dari siswa, dengan persentase $86,65 \%$. Hal tersebut menunjukkan bahwa siswa merasa nyaman ketika menerapkan pembelajaran dengan bahan ajar berbasis way of investigating. Pemanfatan bahan ajar erat kaitanya dengan peningkatan kualiatas pembelajaran yang diharapkan dapat memberikan pengalaman belajar yang bermakna bagi siswa (Materi \& Dan, 2015). Pembelajaran yang bermakna adalah pembelajaran yang dimulai dari lingkungan sekitar.

Bahan ajar merupakan salah satu fasilitas untuk mentransfer ilmu pengetahuan. Bahan ajar yang baik dapat mencakup semua materi dan dikemas secara tepat, sehingga siswa mampu menerima materi dengan baik. Siswa yang dapat dengan mudah menerima dan menguasai materi akan memiliki kemampuan yang lebih bagus (Susanti et al., 2015).

Bahan ajar berbasis way of investigating dalam penelitian ini dikembangakan untuk membantu siswa dalam meningkatkan keterampilan proses (Furqan et al., 2016; Redhana, 2019). Pembelajaran yang berbasis way of investigating mengajak siswa untuk menyelidiki suatu permasalahan dan menemukan jawaban yang dijadikan suatu konsep. Keterampilan proses yang tinggi akan diiringi dengan peningkatan hasil belajar siswa (llmi et al., 2016; Puspita, 2019).

Bahan ajar berbasis way of investigating dapat membantu siswa untuk meningkatkan keterampilan proses untuk menghasilkan konten 
dan membentuk konteks (Yuliati, 2017). Selain itu, bahan ajar berbasis way of investigating yang dikembangkan juga membantu siswa dalam melakukan investigasi terhadap materi Tekanan, karena dalam bahan ajar dilengkapi dengan langkah-langkah yang rinci yang dapat membantu siswa dalam melakukan way of investigating.

\section{KESIMPULAN}

Berdasarkan hasil penelitian dan pembahasan, dapat disimpulkan bahan ajar berbasis way of investigating yang dikembangkan layak digunakan dalam pembelajaran untuk meningkatkan keterampilan proses siswa pada mata pelajaran Fisika materi Tekanan. Bahan ajar yang dikembangkan berkategori valid dengan skor 89,97 dan keterbacaan mudah dipahami ditandai dengan nilai tes rumpang yang tinggi yaitu sebesar 77,88; serta efektif meningkatkan keterampilan proses dengan nilai n-gain 0,33 dengan kategori sedang. Respons siswa untuk penggunaan bahan ajar yang dikembangkan memeroleh persentase $86,65 \%$ dengan kriteria baik.

\section{DAFTAR PUSTAKA}

Cansiz, M., \& Turker, N. (2011). Scientific Literacy Investigation In Science Curricula: The Case Of Turkey. Western Anatolia Journal of Education Science, 1958, 359-366.

Chiappetta, E. L., Fillman, D. A., \&
Sethna, G. H. (1991). A Method To Quantify Major Themes Of Scientific Literacy In Science Textbooks. Journal of Research in Science Teaching, 28(8), 713-725. Furqan, H., Yusrizal, Y., \& Saminan, S. (2016). Pengembangan Modul Praktikum Berbasis Inkuiri Untuk Meningkatkan Keterampilan Proses Sains dan Hasil Belajar Siswa Kelas X di SMA Negeri 1 Bukit Bener Meriah. Jurnal Pendidikan Sains Indonesia (Indonesian Journal of Science Education), 4(2), 124129.

Hanisa, D. (2013). Problem Solving Pada Pembelajaran Gelombang dan Optik Untuk Meningkatkan Keterampilan Proses Sains Mahasiswa. X(2).

Hartono, I. I. M. dan H. S. (2013). Analisis Buku Pelajaran Fisika SMA Kelas XI Yang Digunakan di Salatiga. Unnes Physics Education Journal, 2(2), 71-77.

Ilmi, N., Desnita, D., Handoko, E., \& Zelda, B. (2016). Pengembangan Instrumen Penilaian Keterampilan Proses Sains Pada Pembelajaran Fisika Sma. Prosiding Seminar Nasional Fisika (E-Journal) SNF2016, V,

Kurnia, F., . Z., \& Fathurohman, A. (2014). Analisis Bahan Ajar Fisika SMA Kelas XI di Kecamatan Indralaya Utara Berdasarkan Kategori Literasi Sains. Jurnal Inovasi dan Pembelajaran Fisika, 1(1), 43-47. Lestari, M. Y., \& Diana, N. (2018). Keterampilan Proses Sains 
(KPS) pada Pelaksanaan Pembelajaran. Indonesian Journal of Science and Mathematics Education, 01(1), 49-54.

Mar'ah, A. (2016). Gaya Belajar dan Faktor Pengaruhnya Terhadap Pencapaian Prestasi Belajar IPA Terpadu Siswa Kelas VIII MTs Sultan Fatah Gaji Guntur Demak Tahun Pelajaran 2015/2016. UIN Walisongo.

Materi, S., \& Dan, E. (2015). Pengembangan Buku Ajar IPA Terpadu Berorientasi Literasi Sains Materi Energi Dan Suhu. Journal of Innovative Science Education, 4(2), 34-40.

Muslimin. (2011). Analisis Buku Teks Bahasa Indonesia untuk SMP Kelas IX dengan Pendekatan Tematik. 1(2), 8798.

Puspita, L. (2019). Pengembangan Modul Berbasis Keterampilan Proses Sains sebagai Bahan Ajar dalam Pembelajaran Biologi. Jurnal Inovasi
Pendidikan IPA, 5(1), 79-88. Rahmatillah, R., Halim, A., \& Hasan, M. (2017). Pengembangan Lembar Kerja Peserta Didik Berbasis Keterampilan Proses Sains Terhadap Aktivitas pada Materi Koloid. Jurnal IPA E Pembelajaran IPA, 1(2), 121-130. Redhana, I. W. (2019). Mengembangkan

Keterampilan Abad Ke-21 dalam Pembelajaran Kimia. Jurnal Inovasi Pendidikan Kimia, 13(1).

Sugiyono. (2010). Statistik untuk Penelitian. Alfa Beta.

Susanti, M., Rusilowati, A., \& Susanto, H. (2015). Pengembangan Bahan Ajar IPA Berbasis Literasi Sains Bertema Listrik dalam Kehidupan untuk Kelas IX. UPEJ Unnes Physics Education Journal, 4(3).

Yuyu Yuliati. (2017). Literasi Sains dalam Pembelajaran IPA. Jurnal Cakrawala Pendas, 3(2), 21-28. 
Phy. Educ. Res. J. Vol. 3 No. 2 (2021), 103-112 